\title{
PATHWAYS TO EMPLOYMENT FOR YOUNG NEW ZEALANDERS: EFFECTS OF SOCIAL CAPITAL
}

\author{
Ann Dupuis \\ Kerr Inkson \\ Eva McLaren \\ Labour Market Dynamics \\ Research Group \\ Massey University
}

\begin{abstract}
The Pathways to Sustainable Employment (PASE) research programme is a five-year programme aimed at determining the supply-side and demand-side parameters of employment-seeking and career development of New Zealanders aged 15-34, and developing policy implications. In an initial phase of the project, 866 participants sampled from four geographical areas and representative of different age, gender, and ethnic groups took part in a Computer Aided Telephone Interview (CATI) concerning their employment experiences to date and their aspirations for the future. This paper reports on the experiences of participants in respect of seeking and finding their current job, their last job, and their first job and the role social networks play in supporting career decision making. The data, which demonstrate the key role that social capital plays in these regards, raises issues about such things as the expertise of network members, their objective understanding of others ' capacities and interests, and their knowledge of the labour market. We suggest that the importance of social capital is underestimated and policy makers could do well to take this into account when considering developing strategies for sustainable employment.
\end{abstract}

\section{Introduction}

In recent times, the pathways into employment for younger job seekers have become increasingly problemmatic. Since the 1980 s, traditional conceptions of the nature of paid work and life-time careers have altered, at times dramatically (Arthur, Inkson and Pringle, 1999; Spoonley, de Bruin and Dupuis, 2004). Typically, the transition to employment has been seen in terms of a linear progression from school to work and the pursuit of a career via standard work (Super, 1957; Collin and Young, 2000). More recently, however, paid work has become more precarious. Access to employment is affected by a number of factors including fluctuating unemployment levels, changes in employers' skill requirements, individual and household decisions about training and education investments, national and international policies concerning employment and economic development, and a trend to contingent forms of employment such as part-time, temporary, contract and self-employed work (McLaren et al., 2004; Firkin et al., 2003).

The Foundation for Research, Science and Technology (FRST) funded programme, Pathways to Sustainable Employment (PASE), explores the impact of the changes in the world of work referred to above. The 5-year research programme examines the impact of the increasing variability of employment pathways for both workers and employers. Here we follow the Ministry of Social Development's (2004) definition of sustainable employment which is a high level policy goal that focuses on appropriate employment options for individuals and households at the same time ensuring adequate labour supply for employers and maintaining human capital and social cohesion for New Zealand as a whole.

The broad aims of the PASE project are:

- to explore how 15-34 year olds understand and find or create pathways into employment, and how employers for their part utilise such pathways in their staffing of organisations;

- to establish the extent to which there is an alignment between labour supply and demand, in relation to people within the chosen age cohorts; and

- to provide information through which relevant user-oriented initiatives may be generated leading to sustainable employment for younger people through their meaningful participation in paid work leading to independent adulthood.

The project has two major objectives. Objective 1 investigates supply-side employment issues, in particular the way in which younger people (15-34 year olds) understand and negotiate access to employment. It focuses on the influences on employment of such factors as training and education, skill acquisition, mobility, search techniques, social networks, planning and individual aspirations. Objective 2 has a demand-side focus concentrating on the strategies and expectations of employers in organising labour supply. This paper is concerned only with part of Objective 1.

Objective 1 has both quantitative and qualitative dimensions. The quantitative component involves a Computer Aided Telephone Interview (CATI) survey of a stratified sample of 866 people aged from 15 to 34 years. 
This survey was completed in 2004. It is intended that a follow-up survey will be conducted with the same participants in 2006. As a separate but complementary piece of research, a further 134 Maori participants will similarly be surveyed, using the same interview schedule and followed up in two years time. Thus the total number of participants will be 1,000 . The specific Maori surveys are being undertaken under the direction of Eljon Fitzgerald, Senior Researcher and Co-ordinator of the Te Hoe Nuku Roa research programme at Massey University's School of Maori Studies (Durie et al., 2002). The qualitative dimension will comprise both focus groups and in-depth, open-ended interviews involving 100 participants from the original sample. These will take place in 2005. This conference paper will examine and discuss the findings from the CATI survey of the sample of 866 general participants.

The CATI survey for stage 1 of the project was conducted by a professional Auckland-based research company Consumer Link. Members of the research team developed an appropriate protocol and worked with Consumer Link to ensure that the interviews were properly conducted. Participants were obtained by random digit dialling in the selected geographical areas, and participants meeting the study parameters (i.e. age 15-34) were sought. All interviews were completed in June and July 2004.

The CATI information already generated provides answers by 866 participants to up to 130 questions, many providing multiple pieces of information and some being open-ended. The specific questions asked of each participant depended on their employment status, e.g. student, employed, self-employed, unemployed, caring in the home. Overall it is a large and complex database which will take us many months to analyse and report on in full. However, a major focus was on 'pathways into jobs'. For each participant currently in work we gathered information about their present main employment and how they had found it. For each participant who had ever been employed or who had had employment but were not currently employed, we gathered information about their first and last jobs where applicable.

In this paper we focus on the use of social capital by young people in obtaining employment. To what extent do they report that personal networks as against conventional formal job-application methods are responsible for their finding of jobs? What are the key networks involved and do they change over time? Also, bearing in mind that we are interested in overall career development rather than the simple obtaining of jobs, what role do social networks play in supporting the person in his or her career decision making?

\section{Social Capital and Employment}

According to Bourdieu (1986: 248-249) social capital is the aggregate of the actual or potential resources which are linked to possession of a durable network of more or less institutionalised relationships of mutual acquaintance and recognition - or in other words, to membership in a group - which provides each of its members with the backing of the collectively-owned capital'. Put more simply social capital is the resources one can call on due to one's membership of a group. Bourdieu argues that social capital operates as a credit which group members can call on. The 'volume' of social capital available to individuals depends on the size of their networks and the extent of the various forms of capital those in the networks possess. Social capital is produced through creating and sustaining relationships and interactions with family, friends, neighbours, co-workers and other relatively close associates. It is not necessarily consciously or intentionally pursued, although it can be. In this paper we use social capital in the Bourdieuian sense which should not be confused with a more populist usage of the term (see Firkin, 2001; Lin 2001), or with the academic but more politically oriented usages of such scholars as Coleman (1988) and Putnam (1993) who portray social capital as a public good.

A major strength of the Bourdieuian approach is that it is underpinned by the notion of convertibility of the different forms of capital he identifies: economic, cultural and social capital. An appropriate example of convertibility in the context of finding employment would be through the convertibility of social capital into economic capital as in instances where family and friends, as sources of social capital, provide an individual with information about potential employment or act as a contact between an individual and a prospective employer. If the individual uses the information or pursues the contacts and finds paid employment social capital has effectively been converted to economic capital.

In one formulation of the 'career capital' that individuals acquire, develop and utilise in their employment, three types of capital are identified (DeFillippi \& Arthur, 1996; Inkson \& Arthur, 2001). Knowing-why represents the changing energy, motivation and personal goals that people seek to reach through their work. Knowing-how represents the accumulating qualifications, skills, and experience that they bring to each new job. Knowingwhom is their personal networks and contacts, and also their reputation among others who may not have met them but know of them. This latter form of capital can be likened to social capital. Work organisations and educational and other public institutions tend to focus on assisting people to build their knowing-how and to some extent their knowing-why. The tendency is to ignore knowing-whom capital, or assume that it is up to the individual to develop it without assistance.

It is a truism that gaining favourable employment opportunities is often a matter of "who you know rather than what you know', and that informal contacts are critical to individual career development. A theoretical and more complex variant of this maxim is Granovetter's influential work on the role of social networks (a concept similar to Bourdieu's social capital) in securing employment (Granovetter, 1974). His concept of 'the strength of weak ties' suggests that 'our acquaintances ('weak ties') are less likely to be socially involved with one another than our close friends ('strong ties')'. Weak ties constitute low density networks, whereas strong ties constitute high density networks. An individual will have 
a close friends (and family) who will know one another and acquaintances from a range of interactions who will likely not know one another. Each of these acquaintances, or weak ties, has their own strong ties. The point here is that the weak tie relationship provides 'a crucial bridge between two densely knit clumps of close friends' (Granovetter, 1982: 106) and as such are important in the flow of information among groups. While this view can be applied across a range of situations, Granovetter initially applied it to finding employment and posited that people with few weak ties will have access to much less information about the broad range of job opportunities available. Without weak ties labour market information remains within high density networks only.

It is clear, therefore, that much depends on the heterogeneity of network contacts: those whose contacts are in 'low-density networks' where each network contact has many other network contacts are better placed than those in high-density networks (such as within single families or organisations) where network contacts overlap and have relatively limited external associations (Burt, 1992). This point becomes particularly important in increasingly volatile labor markets as individuals adopt boundary-crossing careers (Raider \& Burt, 1996).

In a recent New Zealand study of 121 job-to-job transitions, in 66 instances (or 55 percent of the sample) the new job had been obtained entirely through personal network mechanisms, while in a further 13 cases (or 11 percent of the sample) personal networks had supplemented formal mechanisms such as newspaper advertisements and formal applications (Arthur, Inkson \& Pringle, 1999). Such networks may violate both best employer practice of 'getting the best person for the job' and EEO principles of avoiding discrimination, but they build valued network reciprocities and trust. On the other hand, there are suggestions that in today's more fragmented, but also more professionalised systems of matching people and employment, the importance of social capital in these situations is declining (Strathdee, 2001).

Studies have demonstrated that using social capital to find jobs does not necessarily result in any better long-term career outcomes for those who use it compared with those who do not (Bridges \& Villemez, 1986; Staiger, 1990.) Much depends on the nature and status of the contacts (Lin, 1999). Because people's social capital tends to be associated with their class and ethnic groups, the use of social capital in employment may over time exacerbate predisposed inequalities. Some sources of social capital are more powerful than others.

\section{Sample Characteristics}

In keeping with Government's interest in the project and the terms of the FRST research contract participants in the CATI sample were restricted to people between the ages of 15 and 34 . In the Auckland area quota sampling was used to ensure that 12 percent of the sample was Pacific peoples and a further 12 percent, new immigrants.

\section{Age and Sex}

The sample was further broken down into four age cohorts: 15-19 years, 20-24 years, 25-29 years, 30-34 years. The proportion of participants in each of these age cohorts is indicated in Table 1. The differences in numbers between the different age-groups doubtless represent their characteristic patterns of leisure and work activity, particularly in terms of being available in the home or being out during the evening.

\section{Table 1: Ages of sample members}

\begin{tabular}{||c|r|r||}
\hline \hline Age & No. & \% \\
\hline $15-19$ & 286 & 33.0 \\
\hline $20-24$ & 190 & 21.9 \\
\hline $25-29$ & 163 & 18.8 \\
\hline $30-34$ & 227 & 26.2 \\
\hline Total & $\mathbf{8 6 6}$ & $\mathbf{1 0 0 . 0}$ \\
\hline
\end{tabular}

In terms of gender, the sample had 479 females (or 55.3 percent) and only 387 males (44.7 percent). This slight imbalance no doubt reflects the fact that females tend to answer the telephone more frequently (Krosnick and Chang, 2001) and co-operate more willingly with surveys than males.

\section{Geographical Location}

In order to ensure compatibility with the Te Hoe Nuku Roa Programme, participants were drawn from one of four regions: Auckland, Wellington, ManawatuWanganui and Gisborne-East Coast. The percentage of participants coming from each area reflected the proportion of the general population in these locations.

Table 2: Geographical Location

\begin{tabular}{||l|r|r||}
\hline & No. & \% \\
\hline Auckland & 534 & 61.7 \\
\hline Wellington & 193 & 22.3 \\
\hline Manawatu/Wanganui & 108 & 12.5 \\
\hline Gisborne & 31 & 3.6 \\
\hline Total & $\mathbf{8 6 6}$ & $\mathbf{1 0 0}$ \\
\hline
\end{tabular}

\section{Ethnicity}

We have been grappling with a way to record the ethnicity of the young adults in our research. It is a complex issue and aggregating responses will always be problematic. As a guide, we consulted with Statistics New Zealand who began a review of the measure of ethnicity in 2000 and work was completed in June 2004 (Statistics New Zealand, 2004). This review has reexamined the classification of ethnicity used in official statistics and one of the main recommendations has been to discontinue the prioritised ethnicity data as standard output. Although this is only a review with the next step being to develop a plan for the implementation of 
recommendations after consultation, we cannot wait for this happen and will use one of Statistics New Zealand's recommendations as a guide to inform our classification. As this is a longitudinal study we need to clarify these issues at the outset.

The revieu (2004: 13-14) has recommended that the standard output for ethnicity data, if it is not based on total responses, will be to have single and combined data. The single/combination output proposed (at level 1) places each person in a mutually exclusive category so each person is allocated to a single category based on whether one or more ethnicities have been reported. So, for example, a person who has given only Maori as their ethnic group will be included in the Maori only category. If a person gave Maori and a Pacific Peoples ethnic group in their response, they would be included in the 'Maori/Pacific Peoples' category. Consequently, Statistics New Zealand has recommended the following:

Single ethnic group: European, Maori, Pacific Peoples, Asian, MELAA (Middle Eastern, Latin American and African) and Miscellaneous (this was the 'other' category). If a person gives two or more responses that fall into the same category, for example, Samoan and Tongan, they will be counted once as 'Pacific Peoples'.

Two Ethnic Groups: Maori/European, Pacific Peoples/European, Maori/Pacific Peoples, Asian European etc.

After looking at our existing data set of 866 people, it became evident that the Asian category is far too broad. Consequently, we have included a new category for pcople from Indian, Pakistan and Sri Lanka (South Asia) to more accurately reflect our sample rather than coding them all as 'Asians'. The remainder of the Asian participants have been coded as 'East Asian'.

Statistics New Zealand has also proposed to continue with the descriptor for the largest ethnic group, namely 'New Zealand European' because there has been objection to the use of the term 'Pakeha' and 'no other suitable term that would be universally acceptable to replace this descriptor was identified from the consultation process' $(2004: 11)$. We prefer to use the term Pakeha/NZ European.

Apart from the specific Maori component available through the Te Hoe Nuku Roa programme, telephone interviewees who identified as Maori were interviewed in addition. Table 3 shows the ethnic breakdown of the CATI sample.
Table 3: Ethnicity

\begin{tabular}{||l|r|r||}
\hline & No. & \% \\
\hline $\begin{array}{l}\text { Pakeha/NZ } \\
\text { European }\end{array}$ & 532 & 61.4 \\
\hline Maori & 51 & 5.9 \\
\hline Pacific Peoples & 79 & 9.1 \\
\hline East Asian & 66 & 7.6 \\
\hline South Asian & 52 & 6.0 \\
\hline MELAA & 19 & 2.2 \\
\hline miscellaneous & 11 & 1.3 \\
\hline Maori/Pakeha & 34 & 3.9 \\
\hline $\begin{array}{l}\text { Pacific } \\
\text { Peoples/Pakeha }\end{array}$ & 13 & 1.5 \\
\hline $\begin{array}{l}\text { Maori/Pacific } \\
\text { Peoples }\end{array}$ & 8 & .9 \\
\hline refused & 1 & .1 \\
\hline Total & $\mathbf{8 6 6}$ & $\mathbf{1 0 0 . 0}$ \\
\hline
\end{tabular}

\section{Employment Status}

The key variable around which CATI was structured was current employment status. It was this element that directed participants to various parts of the questionnaire and allowed us to understand their employment experiences - current, past and future. One clear demarcation was between those who were primarily still students, those who were primarily in the paid work force either full-time, part-time or self-employed, and those who were not in the paid work force. Table 4 below indicates the main categories of respondent. The two largest categories of responses came from those in fulltime work (38.9 percent) and students (33.7 percent). Together these respondents comprise 72.6 per cent of the sample.

Of the sample of 866 people, 615 participants (or 71 percent) were in paid employment, though in only 461 cases (Rows 1 to 3 in Table 3) was this their main activity. Of the 615 respondents, 79.4 per cent were in permanent employment and 20.6 percent had temporary employment.

\section{Table 4: Employment Status}

\begin{tabular}{||r|r|r||}
\hline & No. & \% \\
\hline Self-employed & 31 & 3.6 \\
\hline $\begin{array}{l}\text { Part-time } \\
\text { employment }\end{array}$ & 93 & 10.7 \\
\hline $\begin{array}{l}\text { Full time } \\
\text { employment }\end{array}$ & 337 & 38.9 \\
\hline Student & 292 & 33.7 \\
\hline Carer & 70 & 8.1 \\
\hline Unemployed & 27 & 3.1 \\
\hline $\begin{array}{l}\text { Sickness or invalid } \\
\text { beneficiary }\end{array}$ & 10 & 1.2 \\
\hline Other & 6 & 0.7 \\
\hline Total & $\mathbf{8 6 6}$ & $\mathbf{1 0 0}$ \\
\hline
\end{tabular}




\section{Pathways to Employment}

One question intended to gain information on pathways into current employment was:

\section{'How did you find your current employment?'}

Participants were not given alternatives to choose from, but answered in their own words. Multiple responses were taken account of although in most cases the response fitted only one category, so that 615 respondents in employment yielded 653 responses. The categories, in rank-order of frequency, and the number of participants per category, are shown in Table 4.

Participants were also asked:

\section{'How did you find your first employment?'}

Responses were categorised using the same grouping system. Of the sample of 866 participants, 672 respondents had had at least one job which met the study criteria, and their answers totalling 672 categories, are also given in Table 4.

In terms of social capital, one of the categories was ambiguous. For example, applying in person to an employer may mean applying 'cold' to someone one has never met, or applying to someone in one's network. Accordingly we divided the responses up into three types:

FA (Formal application): individual applies through formal processes or agencies;

SC (Social capital): job obtained through networks, including employer networks; or

OI (Own initiative): job obtained on own initiative without formal availability.

Social capital (SC) was further subdivided in terms of the type of capital - relatives (SCR), friends (SCF), employers (SCE), or school (SCS). This procedure produced the results shown in Table 5 and are summarised in Table 6.
Table 5: Finding Employment

\begin{tabular}{|c|c|c|c|c|c|}
\hline \multirow[b]{2}{*}{$\begin{array}{l}\text { Way of finding } \\
\text { employment }\end{array}$} & \multirow[b]{2}{*}{ Type } & \multicolumn{2}{|c|}{$\begin{array}{l}\text { FIRST } \\
\text { JOB }\end{array}$} & \multicolumn{2}{|c|}{$\begin{array}{l}\text { CURRENT } \\
\text { JOB }\end{array}$} \\
\hline & & No. & $\%$ & No. & $\%$ \\
\hline $\begin{array}{l}\text { Through friends or } \\
\text { other contacts }\end{array}$ & SCF & 152 & 23 & 167 & 25 \\
\hline $\begin{array}{l}\text { Through job } \\
\text { advertisements }\end{array}$ & $F A$ & 151 & 23 & 196 & 29 \\
\hline $\begin{array}{l}\text { Wrote, phoned or } \\
\text { applied in person } \\
\text { to an employer }\end{array}$ & OI & 95 & 15 & 74 & 11 \\
\hline Through relatives & SCR & 59 & 9 & 92 & 14 \\
\hline $\begin{array}{l}\text { Through an } \\
\text { employment } \\
\text { agency }\end{array}$ & $F A$ & 46 & 7 & 27 & 4 \\
\hline Invited to apply & $S C E$ & 32 & 5 & 17 & 3 \\
\hline Self-employed & $O I$ & 20 & 3 & 1 & 0 \\
\hline Internet search & $F A$ & 16 & 2 & 5 & 1 \\
\hline $\begin{array}{l}\text { Worked there } \\
\text { previously or on } \\
\text { temporary job }\end{array}$ & $S C E$ & 16 & 2 & 5 & 1 \\
\hline $\begin{array}{l}\text { Started with the } \\
\text { employer on a job } \\
\text { placement or } \\
\text { training scheme }\end{array}$ & $S C E$ & 16 & 2 & 19 & 3 \\
\hline $\begin{array}{l}\text { Worked there } \\
\text { while studying }\end{array}$ & $S C E$ & 8 & 1 & 8 & 1 \\
\hline Through WINZ & $F A$ & 8 & 1 & 10 & 1 \\
\hline Through school & SCS & 8 & 1 & 12 & 2 \\
\hline Student job search & $F A$ & 4 & 0.5 & 2 & 0.5 \\
\hline $\begin{array}{l}\text { Recruitment } \\
\text { drives }\end{array}$ & $F A$ & 3 & 0.5 & 6 & 1 \\
\hline Don't know & - & 3 & 0.5 & 5 & 1 \\
\hline Other & - & 16 & 2 & 26 & 4 \\
\hline Total & & 653 & 100 & 672 & 100 \\
\hline
\end{tabular}


Table 6: Finding Employment: main types

\begin{tabular}{||l|l|l|l|l||}
\hline & \multicolumn{2}{|l|}{ First Job } & \multicolumn{2}{|c|}{$\begin{array}{c}\text { Current } \\
\text { Job }\end{array}$} \\
\hline $\begin{array}{l}\text { Way of finding } \\
\text { employment }\end{array}$ & No & $\%$ & No & $\%$ \\
\hline $\begin{array}{l}\text { Social capital: relatives } \\
\text { (SCR) }\end{array}$ & 59 & 9 & 92 & 14 \\
\hline $\begin{array}{l}\text { Social capital: friends } \\
\text { (SCF) }\end{array}$ & 152 & 23 & 167 & 25 \\
\hline $\begin{array}{l}\text { Social capital: employers } \\
\text { (SCE) }\end{array}$ & 72 & 11 & 49 & 7 \\
\hline $\begin{array}{l}\text { Social capital: school } \\
\text { (SCS) }\end{array}$ & 8 & 1 & 12 & 2 \\
\hline Social capital: total & $\mathbf{2 9 1}$ & $\mathbf{4 5}$ & $\mathbf{3 2 0}$ & $\mathbf{4 8}$ \\
\hline Formal application & $\mathbf{2 2 8}$ & $\mathbf{3 5}$ & $\mathbf{2 4 6}$ & $\mathbf{3 7}$ \\
\hline Own initiative & $\mathbf{1 1 5}$ & $\mathbf{1 8}$ & $\mathbf{7 5}$ & $\mathbf{1 1}$ \\
\hline Don't know/other & $\mathbf{1 9}$ & $\mathbf{3}$ & $\mathbf{3 1}$ & $\mathbf{5}$ \\
\hline \hline
\end{tabular}

These data suggest that social capital has considerable meaning throughout the employment-gaining experiences of young people, that 'friends and contacts' remain the most important part of social capital. and that relatives are significant in finding the first job but decline in importance thereafter. Despite the value of social capital, however, answering job advertisements appears to be the most frequent single method whereby people find jobs. and increases in importance over time. The own initiative' responses are complicated by the option 'selfemployment, which was chosen by only one participant in relation to first job.

The picture is further complicated by relationships to age. In general. as respondents' age increased the reporting of social capital in finding their current job decreased and formal processes increased. For example, in relation to current job. for those below 25 years of age, 57 percent of responses were in the social capital category and only 23 percent in the formal application category; whereas for those 25 years and over, the equivalent figures were 35 percent and 45 percent - a dramatic shift. Social capital through relations declined rapidly from 21 percent for participants aged under 20 to 3 percent for those aged over 30. In the formal application category, the proportion of people almost doubled as finding employment by answering advertisements went from 13 percent for the under $20 \mathrm{~s}$ to 28 percent for the over $30 \mathrm{~s}$ and use of employment agencies from 3 percent to 9 percent. We surmise that as people gather experience and seek more responsible jobs, employers become more thorough and professional in the procedures they use and the criteria they apply.

\section{Assistance}

Pathways to employment is not just about finding jobs, it is also about choice of educational pathway, choice of occupation, broader career strategies etc. Here too, formal sources of assistance such as counsellors and teachers are available. Participants who were still students were asked:

\section{'Have you talked about your future career to anyone?'}

Of the 292 students, 85 (or 29 percent) said they had not talked to anyone. The responses of the 71 percent of students who had consulted with someone, in answer to the question:

\section{'Who have you talked to?'}

are shown in Table 7.

\section{Table 7: Who Students Spoke to about Employment} Choices by Age

\begin{tabular}{||c|c|c|}
\hline & No & $\%$ \\
\hline Parents & 134 & 27 \\
\hline Friends & 116 & 23 \\
\hline $\begin{array}{l}\text { Career counsellor/ careers } \\
\text { teacher }\end{array}$ & 81 & 16 \\
\hline Other teacher/lecturer & 60 & 12 \\
\hline Other family & 58 & 12 \\
\hline Parents friend & 7 & 2 \\
\hline Possible employers & 7 & 2 \\
\hline Boyfriend/girlfriend & 6 & 1 \\
\hline People in pertinent positions & 6 & 1 \\
\hline Employment agency & 5 & 1 \\
\hline People in further education & 5 & 1 \\
\hline Colleagues at work & 4 & 1 \\
\hline Mentor & 3 & .5 \\
\hline Other & 3 & .5 \\
\hline Total & $\mathbf{4 9 5 *}$ & $\mathbf{1 0 0}$ \\
\hline
\end{tabular}

* this question allowed for multiple responses

The data in Table 7 demonstrate that family and friends are the primary source of students employment and career advice, but that educational advisors also play an important role. Note that these respondents were predominantly in the 15-19 age-group. From this information, 40.2 percent of responses were in the 'family' category (parents 27.1 percent, other family 11.7 percent, parents' friends 1.4 percent). Friends, including boyfriends and girlfriends accounted for 24.6 percent. For this question, however, teachers, lecturers, and careers teachers and counsellors accounted for 29.6 percent of responses. Employers and agencies, with only 2.4 percent of the responses, were seldom consulted about more general career direction.

Age-related data confirmed that the key people consulted changed over time: for example for under-20s, 43 percent of assistance came from family sources, 33 percent from educational sources, and only 21 percent from friends. For over 25-year-old students, the figures were 24 percent, 24 percent and 37 percent respectively. This indicates that as people get older, the reliance on family 
and educational sources declines while that on friends increases to nearly to the same extent. It might be expected as they are leaving educational institutions and the influences of those institutions decline.

We would like to signal that in a later analysis we will further explore social capital with regard to pathways and assistance into employment. This could possibly be problematic for some of the students we interviewed, particularly in immigrant groups which may have strong ties, but their weak ties could be much more tenuous. Table 8 below shows the percentage of the participants in the total sample who identified themselves as students. Of note, is the particularly high number of students in the migrant groups. We are aware that some of these could be foreign students.

\section{Table 8: Ethnicity of Students}

\begin{tabular}{||l|c|c||}
\hline & No. & \% of ethnic group \\
\hline Pakeha/European only & 154 & 28.9 \\
\hline Maori only & 11 & 21.6 \\
\hline Pacific Peoples only & 27 & 34.2 \\
\hline East Asian only & 41 & 62.1 \\
\hline MELAA & 15 & 78.9 \\
\hline South Asian only & 21 & 40.4 \\
\hline Maori/Pakeha & 12 & 35.3 \\
\hline Pacific Peoples/Pakeha & 2 & 15.4 \\
\hline Maori/Pacific Peoples & 4 & 50 \\
\hline Miscellaneous & 4 & 36.4 \\
\hline Refused & 1 & 100 \\
\hline TOTAL & $\mathbf{2 9 2}$ & $\mathbf{3 3 . 7}$ \\
\hline
\end{tabular}

Another question, asked of all participants near the end of the interview after they had reviewed much of their employment experience to date, was:

Now, going back over your employment so far, who has influenced you the most in making your employment choices and how.'

This was an open-ended question and out of the 866 respondents, 285 (or 32.9 percent) found no-one influenced them or they denied any external influence by the response 'myself'. A further 42 did not answer or said the question was not applicable as they had not yet started their career. The people named by the 539 participants who commented on people who had influenced them, and the type of intervention provided, are shown in Table 9.

From Table 9 it is apparent that families and relations are seen to have by far the greatest influence on employment choices, though it declines in relative importance as the individual ages. For 15-19 year-olds, 72 percent of responses were in the SCR (relatives) category, gradually reducing to 44 percent for the 30-34 year olds. In contrast SCE (employer) influences, including work colleagues, increased from 5 percent in the youngest group to 25 percent in the oldest. SCF (friends) increased slightly, from 10 percent to 14 percent and SCS (schools and educational institutions) remained steady at 7-10 percent. No doubt these patterns represent individuals' gradual emancipation from family influences and their increasing reliance on relevant information available in the spheres of their employment. It should also be borne in mind that the question was about the individual's history of employment choices and not just the most recent choice. Nevertheless, the predominance of the family in these data, represented by a total of over 60 percent of responses identifying relatives as major sources of influence, is very striking.

Among family influences, specific mentions of parents (including 'mother' and 'father'), accounted for 83 percent of SCR responses by the 15-19 group, declining to 72 percent for the $20-24 \mathrm{~s}, 54$ percent for the $25-29 \mathrm{~s}$ and 36 percent for the $30-34 \mathrm{~s}$. Also noticeable was the tendency for the mother rather than the father to be singled out by the $15-19 \mathrm{~s}$, and for spouses and partners to increase in importance with increasing age.

As far as the type of intervention was concerned, most of these seemed positive and symbolic, i.e. offering support, advice, and previous experience rather than direct assistance to get a job, though the latter had some importance in the 15-19 group, presumably in relation to first jobs. The 'nagging/hassling' category was largely the preserve of teenagers reporting, 'Mum kept nagging me to go out and get a job' and the like. 
Table 9: Who had the most influence on employment choices? How?

\begin{tabular}{|c|c|c|c|c|c|c|}
\hline PERSON: & $15-19$ & $20-24$ & $25-29$ & 30-34 & Total & $\%$ \\
\hline No-one/'myself' & 64 & 64 & 63 & 94 & 285 & \\
\hline \multicolumn{7}{|l|}{ Relatives (SCR) } \\
\hline Parents & 77 & 34 & 10 & 13 & 134 & 21 \\
\hline Mother & 47 & 13 & 9 & 7 & 76 & 13 \\
\hline 'Family' (non-specific) & 13 & 13 & 13 & 20 & 59 & 9 \\
\hline Father & 22 & 16 & 11 & 4 & 53 & 8 \\
\hline Partner/spouse/boyfriend/girlfriend & 6 & 8 & 9 & 22 & 45 & 7 \\
\hline $\begin{array}{l}\text { Relation not specified in other codes } \\
\text { e.g. aunt }\end{array}$ & 6 & 3 & 2 & 1 & 12 & 2 \\
\hline Sibling & 5 & 1 & 2 & 1 & 9 & 1 \\
\hline \multicolumn{7}{|l|}{ Work environment (SCE) } \\
\hline Boss/employer & 10 & 14 & 17 & 25 & 66 & 10 \\
\hline Work colleagues $(\mathrm{s})$ & 3 & 7 & 3 & 14 & 27 & 4 \\
\hline \multicolumn{7}{|l|}{ Education (SCS) } \\
\hline Teacher (school) & 17 & 4 & 3 & 5 & 29 & 4 \\
\hline Lecturer/tutor & 1 & 11 & 6 & 6 & 24 & 4 \\
\hline \multicolumn{7}{|c|}{ 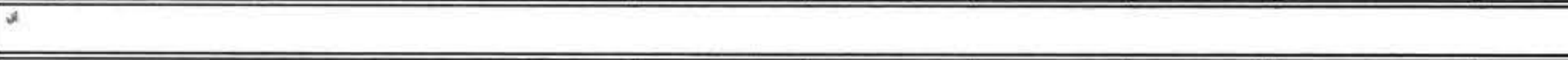 } \\
\hline \multicolumn{7}{|l|}{ Social environment (SCF) } \\
\hline Friends & 22 & 17 & 8 & 17 & 64 & 10 \\
\hline Mentor/coach & 2 & 0 & 4 & 4 & 10 & 2 \\
\hline \multicolumn{7}{|l|}{ Other } \\
\hline God & 0 & 0 & 3 & 5 & 8 & 1 \\
\hline Community Organisation & 2 & 0 & 2 & 2 & 6 & 1 \\
\hline Other & 9 & 5 & 5 & 9 & 28 & 4 \\
\hline Total & 242 & 146 & 107 & 155 & 650 & 100 \\
\hline \multicolumn{7}{|l|}{ TYPE OF INTERVENTION: } \\
\hline Encouragement/support & 32 & 12 & 14 & 23 & 81 & 19 \\
\hline Advice & 25 & 18 & 10 & 14 & 67 & 16 \\
\hline Role modelling/work in same field & 18 & 11 & 14 & 10 & 53 & 13 \\
\hline Nagging/hassling/'go to work' & 33 & 9 & 6 & 2 & 50 & 12 \\
\hline $\begin{array}{l}\text { Options/suggestion/assistance to find } \\
\text { direction }\end{array}$ & 14 & 16 & 7 & 10 & 47 & 11 \\
\hline Information & 10 & 11 & 7 & 10 & 38 & 9 \\
\hline Assistance in getting employment & 20 & 8 & 2 & 4 & 34 & 8 \\
\hline Motivation/inspiration & 4 & 3 & 2 & 5 & 14 & 3 \\
\hline Work assignments & 1 & 3 & 4 & 6 & 14 & 3 \\
\hline Compulsion & 4 & 1 & 2 & 0 & 7 & 2 \\
\hline Promises & 2 & 1 & 0 & 1 & 4 & 1 \\
\hline Other & 8 & 4 & 1 & 2 & 15 & 3 \\
\hline Total & & & & & $424^{*}$ & 100 \\
\hline Not applicable & 6 & 1 & 1 & 1 & 9 & \\
\hline Don't know/not answered & 8 & 6 & 10 & 9 & 33 & \\
\hline
\end{tabular}

* not all those who reported being influenced stated what type of influence it was. 


\section{Conclusions}

This paper is the first output of the FRST funded 'Pathways to Sustainable Employment' (PASE) Research Programme that aims to explore the impact of recent changes in the world of work on employment pathways for both younger workers and employers. The paper reports on two employment related issues that emerged from a CATI questionnaire of a sample of 866 respondents who were aged between 15 and 34: how participants found jobs and the assistance sought in their job seeking efforts.

About a third of the participants did not mention any form of contact used in seeking current or first job. Furthermore, 29 percent could not identify anyone who had influenced them in their employment choices. Such responses may of course be due to psychological effects of 'attribution effect' (Heider, 1958) or 'internal locus of control' (Rotter, 1966) whereby individuals prefer to consider themselves the authors of their own destinies, particularly if they see themselves as having been successful. Nevertheless it is of concern that ostensibly many young people perceive themselves, whether by choice or by chance, to have traversed their pathways to employment unassisted.

The PASE data demonstrated that for our participants, family, friends and other associates were an important means of finding employment. Among the majority who apparently employed social capital, we were struck by the influence of the family, particularly parents, as the main apparent source of contacts, advice, role modeling, and career choice. There is plenty of evidence to suggest that to a considerable extent, individuals 'inherit' their parents' careers, at least in terms of being tied to particular social classes (Goodale \& Hall, 1976; Jacobs, Karen \& McClelland, 1991). Arguably, this may lead to restricted ambition, predominantly among those whose parents' occupations confine them to lower socioeconomic strata. Particularly in the early steps along the pathway, parents' social capital is more important to young people than their own. Parents' networks may be restricted or 'dense'. For example with much family overlap, leading to high norms of trust and reciprocity but limited opportunities, or by contrast they may be 'open', leading to increased ranges of opportunities but also higher risk of marginalisation (Stone, Gray and Hughes, 2003).

Similarly, if parents are the key career advisors and counsellors for young people, there have to be questions about such things as their expertise, their objective understanding of their children's capacities and interests, and their knowledge of the labour market. From a policy point of view, if we seek to optimise young people's employment choices, the balance between family and 'community' social capital seems an issue well worth addressing (Israel, Beaulieu and Hartless, 2001).

On the whole we would argue that the importance of social capital is underestimated both in theory and in practice concerning employment-finding. Theories of career choice tend to focus largely at the level of the individual career decision-maker and his or her interests, career maturity, and other internal psychological variables (e.g. Brown, 2002). Formal processes of vocational guidance may also be overly linked to the notion of the autonomous self-helping individual. Even where individuals become more mature, they may not fully appreciate the ways in which building social capital, as well as becoming part of the social capital of others, can assist career development. In the forthcoming stages of our work, both in focus groups follow-up, our second survey and our work with employers, we intend to give this dimension a special focus.

\section{References}

Arthur, M. B., Inkson, K., and Pringle, J. K. (1999). The new careers: Individual action and economic change. London: Sage Publications.

Bourdieu, P. (1986). The forms of capital. In J. Richardson (ed.), Handbook of theory and research for the sociology of education (pp.241258). New York: Greenwood.

Bridges, W. P. and Villemez, W. J. (1986). Informal hiring and income in the labor market. American Sociological Review, 51, 574-582.

Brown, D. (2002). Career Development and Choice. San Francisco: Jossey-Bass.

Burt, R. (1992). Structural holes. Cambridge, MA: Harvard University Press.

Coleman, J. (1988). Social Capital in the Creation of Human Capital. American Journal of Sociology, 94, nSUPP, pp. pS95-121.

Collin, A. and Young, R. A. (2000). The Future of Career. Cambridge: Cambridge University Press.

DeFillippi, R. J., and Arthur, M. B. (1994). The boundaryless career: a competency-based perspective. Journal of Organisational Behavior. 15, 4, 307-324.

Durie, M., Fitzgerald, E., Kingi, T., McKinley, S and Stevenson, B. (2002). Maori Specific Outcomes and Indicators. A Report Prepared For Te Puni Kōkiri, The Ministry of Māori Development by Te Pūtahi a Toi, School of Māori Studies, Massey University, Palmerston North.

Firkin, P. (2001). Entrepreneurial Capital - A ResourceBased Conceptualisation of the Entrepreneurial Process. Working Paper No. 7 - Labour Market Dynamics Research Programme, Albany and Palmerston North: Massey University.

Firkin, P., McLaren, E., Spoonley, P., de Bruin, A., Dupuis, A., Perera, H. and Inkson, K. (2003). Non-Standard Work: Alternative Working Arrangements amongst Knowledge Workers in Hawkes Bay and Auckland: An Expanded Analysis Across Two Regions. Research Report No. 4, 
Labour Market Dynamics Research Programme, Albany and Palmerston North: Massey University.

Goodale, J. G., and Hall, D. T. (1976). On inheriting a career: the influence of sex, values and parents. Journal of Vocational Behavior, 8, 19-30.

Granovetter, M. (1974). Getting a Job: A Study of Contacts and Careers. Cambridge, Mass.: Harvard University Press.

Granovetter, M. (1982). The Strength of Weak Ties: A Network Theory Revisited. In P. Marsden and N. Lin (eds) Social Structure and Network Analysis. Beverly Hills: Sage Publications, pp. 105-130.

Granovetter, M. (1995). Getting a job: A study of contacts and careers (3rd. Ed.). Cambridge, MA: Harvard University Press.

Heider, F. (1958). The psychology of interpersonal relations. New York: Wiley.

Inkson, K., and Arthur, M. B. (2001). How to be a successful career capitalist. Organisational Dynamics, 31, 3, 48-61.

Israel, G. D., Beaulieu, L. J. and Hartless, G. (2001). The influence of community and family social capital on educational achievement. Rural Sociology, 66, 1, 43-68.

Jacobs, J. A., Karen, D., and McClelland, K. (1991). The dynamics of young men's career aspirations. Sociological Forum, 6, 609-639.

Krosnick, J. A. and Chang, L. (2001). A Comparison of the Random Digit Dialling Telephone Survey Methodology with Internet Survey Methodology as Implemented by Knowledge Networks and Harris Interactive. Ohio State University.

Lin, N. (1999). Social networks and status attainment. Annual Review of Sociology, 25, 467-487.

Lin, N. (2001). Capital - A Theory of Social Structure and Action. Cambridge and New York: Cambridge University Press.
McLaren, E., Firkin, P., Spoonley, P., Dupuis, A., de Bruin, A. and Inkson, K. (2004). At the Margins: Contingency, Precariousness and Non-Standard Work. Research Report 2004/1, Albany/Palmerston North: Labour Market Dynamics Research Programme, Massey University.

Putnam, R. (1993). The Prosperous Community: Social Capital and Public Life. American Prospect, 13, $32-45$.

Raider, H. J. and Burt, R. S. (1996). Boundaryless careers and social capital. In M. B. Arthur and D. M. Rousseau (Eds.), The boundaryless career: $A$ new employment principle for $a$ new organisational era pp. 187-200. Oxford: Oxford University Press.

Rotter, J. B. (1966). Generalised expectancies for internal versus external control of reinforcement. Psychological Monographs, 80, 609.

Spoonley, P., Dupuis, A., and de Bruin, A. (2004). Work and working in twenty-first century New Zealand. Palmerston North: Dunmore Press.

Staiger, D. (1990). The effects of connections on the wages and mobility of young workers. Cambridge, MA: MIT Press.

Statistics New Zealand (2004). Report of the Review of the Measurement of Ethnicity June 2004. Retrieved from www.stats.govt.nz.

Strathdee, R. (2001). Changes in the social capital and school-to-work transition. Work, Employment and Society, 15, 2, 311-326.

Stone, W., Gray, M., and Hughes, J. (2003). Social capital at work: how family, friends and civic ties relate to labour market outcomes. Research Paper No. 31, Australian Institute of Family Studies, April.

Super, D. E. (1957). The psychology of careers. New York: Harper and Row. 